\title{
Critique, Comparison, Suffering, and the Middle East
}

\begin{abstract}
This paper recapitulates two influential JRAI articles to discuss comparison in anthropology. Charles Lindholm's 1995 article criticized the then new, now well-established, trend in Middle East ethnography for its radical emphasis on particularism and lack of theorization, driven by fears of de-humanizing subjects. In turn, Joel Robbins's 2013 article proposed an "anthropology of the good" as a substitute to the particularism of the anthropology of the "suffering subject". This would reinstate the notion of cultural diversity and its comparative vocation as touchstones of contemporary anthropology. Connecting these articles is a discussion of Middle East and Palestine ethnography's major shift in the 1970's to an anthropology of suffering reflected in anthropology at large. The conclusion is that suffering, just as comparison, must be qualified. Thus, qualified comparison must be the foundation to anthropological critiques of Western reason as much as it is to classical cultural critique.
\end{abstract}

Keywords: Middle East, Palestine, comparison, suffering, anthropological theory.

\section{Introduction}

A breeze began to blow as we moved slowly along the coast road, heading to the Lebanese border - my mother and father, my two sisters, my brother and I. Behind us lay the city of Haifa, long the scene of bombing, sniper fire, ambushes, raids, and bitter fighting between Palestinians and Zionists. Before us lay the city of Sidon and indefinite exile. Around us the waters of the Mediterranean sparkled in the sun. Above us eternity moved on unconcerned, as if God in his heavens watched the agonies of men, as they walked on crutches, and smiled. And our world had burst, like a bubble, a bubble that had engulfed us within its warmth. 
From then on I would know only crazy sorrow and watch the glazed eyes of my fellow Palestinians burdened by loss and devastated by pain". [...] "Whenever Palestinians met in those days they would reach out to touch that vibration of intimacy, the sharing of a pain now blinding the eyes, and the intangible qualities of mind that made 'us' and excluded 'them'. We became close, reached closer, as if to be equals in the sharing of our burden, our loss. The formalities that had distinguished or separated us in Palestine - the intellectual from the semi-literate, the professional from the artisan, the middle class form the upper class, the rich from the poor, the pious from the unbeliever, the Christian from the Moslem - were imperceptibly dropped" (Turki 1974: 43,44, 52).

In the above passage Fawaz Turki, a famous Palestinian writer, himself raised in and around a Palestinian refugee camp in Lebanon, expresses what he sees as the crucial workings of Palestinianness since 1947: shared feelings of "crazy sorrow", "burden by loss", "devastation by pain". Themes such as feelings, loss, and pain, traditionally left out of anthropology before the 1970's, have become fertile ground in anthropology today, and particularly in Middle East and Palestine anthropology. More than being absorbed into the traditional psychological anthropology field, a whole new area, what has been called the "anthropology of suffering" (see Fassin 2013, 2012; Robbins 2013; Feldman, Ticktin 2010; Das 2007), is accommodating these topics. While this broadening of the field happened in a moment some branded as a crisis in anthropology (Lindholm 1995), it can also be argued that this was a moment of deep theoretical introspection, characterized by a critical revaluation of anthropology's own cannon and unfathomable attention to ethnographic detail. However, some claim that one of the most important inclinations of anthropology might have been seriously crippled along the way, namely, its comparative vocation. Has this really happened? If so, should current anthropology recuperate this vocation? Moreover, in doing so, would it risk losing the critical character it has gained in the last few decades? Does comparison inherently obliterate the voice of those among whom anthropologists study?

This article seeks to engage these questions through Middle East and particularly Palestine ethnography. First, I will recall Charles Lindholm's panorama of Middle East ethnography in the early 1990's and Furani and Rabinowitz's panorama of contemporary Palestine ethnography to situate the main trends of these subfields of anthropology - especially the establishment of "radical particularism" as ethnographic strategy and the rise of the anthropology of suffering. By radical particularism I mean the analytical principle that broad "etic" comparative categories necessarily entail the critical loss of a given social group's distinctiveness and uniqueness to the point where comparison should be morally avoided. Social suffering, a main topic within contemporary anthropology, will be subsequently contextualized to inform my positioning about current anthropology and especially its frequently lost comparative vocation. 


\section{The Once New Middle Eastern Ethnography}

In 1995, Charles Lindholm published a polemic article entitled The New Middle Eastern Ethnography at the "Journal of the Royal Anthropological Institute". Creatively, Lindholm chose a multiple book review format to address what he perceived then as the broad contemporary tendencies of the field. The six books analyzed were: Writing Women's worlds, by Lila Abu-Lughod (2008); Everyday Life in the Muslim Middle East by Donna Bowen and Evelyn Early (1993) - a collection featuring, among others, Dawn Chatty, Dale Eickelman, Steve Caton, Lila Abu-Lughod, and Elizabeth Fernea; Struggle and Survival in the Modern Middle East, by Edmund Burke (1993) - another collection, featuring among others, Lila Abu-Lughod, Sami Zubaida, Michael Fischer, Akram Khater, and Philip Khoury; The Victim and its Masks: an Essay on Sacrifice and Masquerade in the Maghreb, by Abdellah Hammoudi (1993); The Caligraphic State: Textual domination and History in a Muslim Society, by Brinkley Messick (1993); and Religion and Power in Morocco, by Henry Munson (1993) - all books published in 1993. While a few of these authors were not anthropologists per se, all of them widely engaged Middle Eastern ethnography. According to Lindholm, these works also had in common being published at a time when "moral and theoretical challenges" to classic anthropology and the concept of "culture" brought about "a deep crisis in Middle Eastern ethnography", these books being responses to such a crisis. The general trend was a "recourse to personal narrative and biography" to "humanize ${ }^{1}$ the Other, but at the expense of any possibility of theory building or comparative work" (Lindholm 1995: 805).

Lindholm was certainly not the only one to think back in 1995 that "a deep crisis" had "shaken Middle Eastern anthropology to its roots" (p. 805), and the authors of the works he analyzed tended to be more optimistic, seizing the moment as one of profound renewal. Thus, while both sides agreed that around 1993 was a moment of inflexion, there was enormous potential for those being criticized to resent those who criticized them, and vice-versa. Rallying from the other side, it was not without resentment either that these "new Middle Eastern anthropologists" challenged the establishment. However, it is also important to notice that the momentum reconvened many among the established scholars around what they perceived as radical change. What was the "classic" Middle East anthropology, and how did it change? How influential are the books and authors reviewed by Lindholm 20 years later? Did the tendency that Lindholm highlighted then catch on? If so, is it still new, established or dépassé? What were the advantages and pitfalls then, and how are these perceived today?

1 Throughout this article, the italicized terms related to Humanism, Humanitarianism, the Human condition, precariousness, and suffering are always my own, unless otherwise indicated. 
While a few of the authors reviewed by Lindholm were rising stars in 1993, virtually all of them are today well established in the field. That in itself is evidence that at least some of the recipes contained in these books became part of the canon today. But what are these recipes, and how much do they represent the present and future of the discipline?

According to Lindholm, traditional anthropology in the "largest cultural area" in terms of square miles in the "anthropological division of the world" had been about themes such as "independent herdsmen in the remote deserts or tribal farmers in the rugged mountains". Such areas, marked by the "ethos of Islam and the austerity of social life" and unconducive to elaborated symbolic systems, the flourishing of myths, and intricate ritual performances, gave rise to an anthropology of public matters such as "honor", "survival", "political and marital alliances", "respect and authority", and "patrilineage" (Lindholm 1995: 805). Meanwhile, generations of Orientalists had concentrated their study on Islamic history and literature, revealing a rich urban cosmopolitism (Lindholm 1995: 805) tied to the "Golden Age" of Islam (Kassir 2006). This division between one ethnographic egalitarian, current and peripheral, as opposed to an Orientalist textual, historical, central and status-conscious Middle East survived until the assault of Edward Said's Orientalism in 1979, which rendered both approaches "morally suspect" - to use Lindholm's own terms. Said's main argument was that both traditions conjured representations composing imaginative geographies that served a colonial project of domination. While "Orientalism was a rationalization of the colonial rule" (Said 1979: 39), anthropology was an instrument for the reiteration of the "binomial opposition of 'ours' and 'theirs' with the former always encroaching upon the latter" (Said 1979: 227). What Lindholm emphasized is that, to Said, both the textual and the empirical lines of study by Westerners "denied humanity to Middle Eastern people by turning them into exotic 'Others' to be gazed at and objectified" (1995: 806).

The rift between "classical" and "new" begins with Lindholm's protests that Said's view of culture is that it is merely "hegemonic and disciplinary" (following Clifford 1988: 263) and that there was no outcry against this perspective in anthropology because it fit well within the "anti-comparativist and anti-essentialist" trend of anthropology at the time (see also Varisco 2004). Among those backing these radical ideas were two scholars of the Middle East: Clifford Geertz and Pierre Bourdieu. Although neither worked within the narrowest definition of Middle East as a cultural area ${ }^{2}$, both worked in the Arab North Africa, and had a strong impact on Middle Eastern anthropology. Geertz in particular was instrumental in turning anthropology away from the study of "tribal kinship organizations" and "egalitarian social structure" and towards "the construction of meaning" in "complex urban" settings. According to Geertz and Bourdieu, kinship and

2 Lindholm defines what he calls "the Middle East" as a much wider cultural area (2002). See also (Schiocchet 2011). 
tribal egalitarianism had been erroneously taken as normative structures generating practice, "mistaking native ideology for reality" (Lindholm 1995: 807). Due to Geertz and Bourdieu's roles, Middle Eastern anthropology, more so than the rest of the discipline, suffered the consequences of this predicament. Old premises were largely abandoned, and there was space for a new theory of social life in the Middle East. However, Said's "rhetoric of opposition" had nothing in the way of usable theoretical models. Moreover, Bourdieu changed his focus to France, leaving the field open to Geertz's students and sympathizers, such as Dale Eickelman, Lawrence Rosen, Victor Crapanzano, Paul Rabinow, and Michael Fischer. According to Lindholm, Middle Eastern anthropology, propelled by the guilt aroused by Said's indictment, became subsequently "cripplingly self-conscious" (1995: 808), while allowing the subjects to speak in their own words became a mantra.

According to Lindholm, Messick's response to the "deep crisis" of the field was not as "exemplary" as Hammoudi's (1993), although still insightful. It consisted of combining "anthropological methods, textual exegesis and historical study", thus "trespassing" "into the formerly sacrosanct urban, learned and courtly domain of the Orientalists" to discuss the institutionalization of "domination and subordination" in the "Middle Eastern milieu". In the same vein, Lindholm also saw Rosen (1989), Eickelman (1985), Fischer (1980) and Richard Antoun (1989) as insightful trespassers. This trend followed closely Talal Asad's postcolonial critique, as evidenced by Messick's initial quotation of Asad: "if one wants to write an anthropology of Islam one should begin, as Muslims do, from the concept of a discursive tradition that includes and relates itself to the founding texts of the Quran and the hadith" (Asad 2009: 14; Lindholm 1995: 813). However, for Lindholm, Messick "is infected by the postmodern assertion of the priority of the text", and guilty of "ponderous language", "rhetorical excess" and absence of bold theorization - in this case, despite the rich material presented (Lindholm 1995).

The other venue, which became much more popular, was that of "social biography, novelistic narrative and personal accounts", which Lindholm characterizes as being at the core of postmodern (or "new") Middle Eastern anthropology. To him, Abu-Lughod's book epitomized this trend, with Bowen and Early and Burke's books following it closely. The essays on Bowen and Early's collection "successfully conjured up the aroma, the variety, the humanity, and even some of the history of the Middle East". However, out of the thirty-four, only two "notable exceptions" (Gilsenan's and Betterridge's) "offered anything more". Similarly, the results of Burke's "biographical-literary approach" were "almost always evocative, colorful and humane", but "rarely of much theoretical interest" due to "an unwillingness to accept responsibility for theorizing or abstraction" which hinders the essays from "any useful premises or hypotheses" (1995: 812).

Lindholm dedicates roughly half of his article contextualizing Abu-Lughod's work, which he sees as the prototype of the "crippling" response to the crisis he professes. On the one hand he praises her book for being "expertly and intelligent- 
ly written", and herself for championing "the study of previously ignored aspects of ordinary lives", for documenting "the discourse of emotion among women", and for being "human" in "her attention to personal stories and to the pleasures and travails of daily life". On the other hand, however, he opposes her call "for the 'undoing' of old Middle Eastern anthropological categories". To Lindholm, AbuLughod's furthering of Said's indictment meant that:

to typify the Middle East as a cultural region, or to understand Middle Easterners as having a particular cultural heritage, or even, it seems, to imagine others as separate from ourselves, is an act of aggression, and that all forms of distinction should be refuted as a fundamental moral evil (Lindholm 1995: 809).

He acknowledges that her project is "more affirmative" than Said's, and he describes her project, largely using her own words, as consisting in giving "positive content to her subjects through 'a narrative ethnography' consisting of 'wonderfully complex stories' which 'challenge the capacity of anthropological generalizations to render lives, theirs or others', adequately". Nevertheless, he eschews Abu-Lughod's stance for rejecting what I understand as being the main ingredients to comparison, such as "detachment", "abstraction", and "generalization", which he says Abu-Lughod considered to be alienating (Lindholm 1995: 810). Incidentally, Abu-Lugoud's ideas were particularly influential in the broad field of anthropology at large at least since her seminal Zones of Theory in the Anthropology of the Arab World, published in 1989, and this may have also motivated Lindholm to engage with her work more incisively. He urged us then to consider the quandaries that result if we follow "her call for an active effort to disintegrate all boundaries, including the boundary between self and other" (Lindholm 1995: 810). His qualms here are especially with what he sees as a radical particularistic "moral assumption" that one should not compare, when to him anthropology is intrinsically comparative. He explains that, according to the "new" group, epitomized by Abu-Lughod, to compare inescapably implies asymmetrically departing from a position of superiority, given that at the very least the anthropologist is the one who sets the rules of the game. Or, in her own words, "at the very least, the self is always the interpreter and the other the interpreted" (Abu-Lughod 2008: 13).

Lindholm was worried then that the lack of comparison and the radical emphasis on particularism might have lead today to a total absence of theorization. In this sense, it is also important to acknowledge that the particularistic trend had great impact in other subfields of anthropology as well. For example, in 2003, Elizabeth Colson (2003) was still urging the anthropology of forced migration to reconsider its emphasis on particularism in detriment of comparative work a trend that, according to her, was largely promoted by Liisa Malkki (1995), just a couple of years after 1993. This not to say Malkki did not theorize, only that the largely comparative focus of anthropology, especially as represented by the etic category "refugee", had to be deemphasized, while attention to detail had to be put 
at the core of the anthropological effort. It can hardly be denied, however, is that in the early 1990's much theorizing indeed occured in anthropology, but less so about the societies that anthropologists study and more so about methodological approaches to ethnography and the portrayal of "the Other" along with the dangers of othering. Hence, another way to approach that moment is to perceive it, as I do, as a deep introspection necessary to reevaluate the practice of anthropology in a changing world. Indeed, much has changed, and while I evaluate the effects of that rebellious moment as crucially positive, and today I inscribe my own anthropology well into the "New Middle Eastern Ethnography", perhaps it is time to reconsider one of Lindholm's main qualms: radical particularism. In seeking to reinvent and rid itself of the shackles of its colonial past, did anthropology cripple its own comparative vocation? In trying to redefine humanity, was it reduced to a cultural critique of the normative? It is undeniable that nowhere else does Said's critique of Orientalism, and perhaps even Asad's critique of the colonial encounter, reverberate as much as in Palestine anthropology. Thus, this is precisely where we should head to consider these questions further.

\section{Arriving at the Hazardous Theory Zone of Palestine Ethnography}

One notion omitted from Lindholm's 1993 considerations is that the new Middle East anthropology has indeed become more Middle Eastern. Having subscribed to the postcolonial anthropology project myself, along with Lindholm himself 3 , I consider this an advantage $e^{4}$. Khaled Furani and Dan Rabinowitz also expressed a similar position in a piece published in 2011 in "The Annual Review of Anthropology", while reflecting on the division of labor between Westerners and their Others, and the production of anthropological theory and its sites. This article aimed at considering "Palestine as a problem space that could reinvigorate the critical abilities of postcolonial language and the anthropology that it engenders" (2011). Through sketching the history of Palestine ethnography, these authors welcome the making of Palestine as a site for the production of theory, rather than just otherness. As Furani stated in a lecture about the article in 2011 at the Center for Contemporary Arab Studies at Georgetown University (CCAS) (2011), "Will Palestine bring to lands of Europe its own theory and change its epistemic status?". In asking this question, the article thus aims at coming to terms with Said's concept of "traveling theory", and "with the place of Palestine in the Western con-

3 Personal communication, 07/2014.

4 In a personal communication in $07 / 2014$, Lindholm reiterated to me that he also welcomes this change. 
sciousness, in Western critical inquiry, and Humanist tradition", discussing whose theories and facts are mobile (2011).

After the Oslo and the Madrid peace processes in the 1990's, ethnographic research on Palestinians, which today is largely perceived in association with Palestinian activism, saw a sharp increase. This contemporary interest in Palestine as an ethnographic site, and its legitimacy, are embedded in two interrelated "epistemological-political conditions" or shifts. The first is the "demystification of nations and the ethnic groups that formed them, and a corresponding surge in the legitimacy afforded to groups with counterclaims". The second is what Furani and Rabinowitz call the "crisis of representation' within anthropology and beyond it", or Lindholm's "deep crisis" (Furani, Rabinowitz 2011: 476; Lindholm 1995). Both of these can be understood as "broad critiques of Modern Western reason", within which Palestine "as an anthropological subject" flourishes (Furani 2011).

According to Furani and Rabinowitz, there have been four different modes of approaching Palestine as a site for inquiry since the late $19^{\text {th }}$ Century that may overlap. The first is the "proto-anthropological", and it dominates until the late 1940's. It is external (more than simply "etic"; analyzed from the outside of the territory), proto-ethnographic and the bible is its legitimizing text. The second is also external, but secularized. Dominating from the early $20^{\text {th }}$ Century until the late 1940 's, is the "Orientalist" approach, which incorporated participant observation and fieldwork, and brought about a vocabulary change. Instead of Holy Land and Mohammedans, popular terms are Palestine, primitives, race, Muslims, Orientals, and Arabs. It is permeated by Social Evolutionary and Functionalist presuppositions, and concerned with stability, rule, integration, differentiation, and evolution of social forms, besides the documentation of disappearing cultures (what has been termed "salvage Anthropology"). The third mode of approaching Palestine is called "absent Palestine", and it is characterized by very little engagement with the Palestinian subject. This mode was predominant between 1948 and the late 1980's, or between the foundation of Israel and the First Intifada. Two areas in particular glaringly demonstrate the absent Palestine: peasant and refugee studies both understood as hazardous in that they reveal Palestinian attachment to the land, thereby leaving the field open to Zionist anthropology, focusing on Palestinians as "traditional" but naming them Arabs instead (Furani, Rabinowitz 2011).

Like Lindholm, Furani and Rabinowitz understand that Edward Said's Orientalism precipitated a radical change in the field, while also adding Talal Asad's Anthropology and the Colonial Encounter to this genealogy ${ }^{5}$ an addition with which Lindholm would perhaps not disagree. Both books were published in the late 1970's and preannounce the coming in the late 1980's of the fourth and final mode of engaging Palestine as a site. This largely corresponds to what Lindholm called "new Middle East ethnography", which the latter authors prefer to

\footnotetext{
5 It is important to notice that Furani was himself a student of Talal Asad.
} 
call "post-structural". Here, no longer silent and self-evident, the state becomes an object of inquiry to "a new generation of anthropologists who begin to question Israel's effort at repressing Palestinian nationalism and normalizing its racial and colonial character". Palestine and Palestinians reemerged as subjects, especially through themes such as "memory", "refugees", "resistance", "national identity", "colonial predicament", and "gender", but also through "law", "prison", "bureaucracy", and a host of new topics (Furani, Rabinowitz 2011; Furani 2011). Meanwhile, Palestinian native ethnography finally began to flourish in the late 1970's due to a double political and epistemological shift as a response to, respectively, the 1967 Arab-Israeli War and the "crisis" ushered by Said and Asad. Besides these two authors, Palestinian ethnography also engaged figures such as Michel Foucault, Del Hymes, and Eric Wolf. According to Furani, the whole of postcolonial, poststructural, postmodern anthropology - and I would add post-Zionist studies - offers what he calls, paraphrasing Said this time, an "enabling vocabulary" to study the Palestinians, the most preeminent of these notions being "memory". "Memory, unlike truth, is a more hospitable place for the precarious yet persevering truths of the Palestinian condition" (2011).

Yet, I would like to highlight that, along with memory, "refugeeness" is also central to many ethnographies about Palestinians, especially among those working in Lebanon, as we shall see from a brief inventory. Many ethnographers of Palestinians at some point worked on memory, and some of the most relevant of these are: Sharif Kanaana (2000, 1989), Bishara Doumani (1995), Ted Swedenburg (1992, 2003), Susan Slyomovics (1998), Lena Jayyusi (2007, 2002), Lila Abu-Lughod and Ahmad Sadi (2007), and Rema Hammami (2003). However, even more revealing is the number of Palestine ethnographers working on the Middle East that tended to engage directly "refugeeness", almost all of them associating it to "memory", "suffering", "resistance", "national identity", and/or "gender". Some of these are: Rosemary Sayigh $(1979,1994,2007)$, Julie Peteet $(1987,1994,1996 a$, 1996b, 2005), Laleh Khalili (2005, 2007), Rhoda Ann Kanaaneh and Isis Nusair (2010), Rochelle Davis (2010), Lori Allen (2013), Diana Allan (2014), Moslih Kanaaneh (Kanaaneh, Thorsén, et al. 2013), Randa Farah (2003, 1998, 1997), Lotte Segal (Segal 2014a, 2014b), Ruba Salih (2013), Lori Lybarger (2007), Nell Gabiam (2006), Amanda Dias (2013), Gustavo Barbosa (2013), and my own work (Schiocchet 2015, 2013). Few are those anthropologists engaging Palestine with broad foci on theoretical categories themselves (apart from aiming to deny their usefulness), or bolder comparative intentions. Some of the most interesting in this sense are by Didier Fassin (2008) and Michel Agier (2008, 2011), who only wrote on Palestinians en passant, the latter becoming interested specifically in Palestinians only recently. Other examples are Dawn Chatty (2010) and Knudsen, Hanafi (2011), who come respectively from Middle Eastern mobility and Arab Studies toward Palestine as a site, the latter being also interested in Islamism and South 
Asia. As a final example, Ilana Feldman's work (2008) engages directly Humanitarianism and governmentality.

Overall, along with Furani and Rabinowitz I understand that Palestine ethnography today is primarily concerned with how Palestinians are locked into a bind between repression and resistance epitomized by what Furani calls "narratives about the national struggle" (2011), or what I would call the Palestinian polysemic engagement to al-Qadyia al-Falastynyia ("The Palestinian Cause"). According to Furani and Rabinowitz, this means that attention is taken away from other topics such as "environment", "land alienation", "employment", "language", "sexuality", "piety", "food" and "health" (Furani, Rabinowitz 2011; Furani 2011).

On the one hand, what is missing from their account is the logic that binds these neglected themes together. I also have reservation about the particular inclusion of "land alienation" and "piety" in this list. While I agree that indeed both themes have not been the primary focus of much anthropological research ${ }^{6}$, land alienation is accounted for and embedded in many of the works cited in this section. As for religion and piety, both are integral to the work of a number of authors (Knudsen 2003a, 2003b), (Abufarha 2009), (Bowman 2013, 2011a, 2011b), (Lybarger 2007), (Saar 1998) $)^{7}$, (Rougier 2007) $)^{8}$, (Suhr 2013) ${ }^{9}$, and (Kublitz 2001, 2016). My own work aims at showing that piety is often inextricably tied to the "secular" rallying for "The Palestinian Cause" in practice (Schiocchet 2015, 2013, 2011).

On the other hand, I agree with Furani and Rabinowitz's project of including Palestine as a site for the production of theory, and I especially welcome the emergence of a Palestinian and Middle Eastern anthropology as a counterpoise to a "Western anthropology" about Palestine and the Middle East. However, it should be recalled that such a project is inherently comparative, and that it thus ineluctably entails the retrieval of anthropology's comparative vocation and (once more in the history of the discipline) the rethinking of the radical particularistic approach. In other words, taking Furani and Rabinowitz's argument to heart leads to acknowledging that the present state of affairs in Palestine ethnography (as for anthropology in general) has led to a relative lack of studies of topics that do not relate directly to the "witnessing" of particular "suffering subjects". This, in turn, has led to a lack of bolder midrange comparative analysis often projecting Palestine out of Middle East ethnography. Thus, besides the themes mentioned by Furani and Rabinowitz in their article, examples of what is deficient today in

6 However, both topics have been developed in other fields: land alienation in law, international relations and refugee studies; and religion and piety in Islamic Studies.

This article is more about religion as sectarian belonging than it is about piety.

8 It should be noted that Rougier is not an anthropologist per se, however, he states having done ethnographic research in Ayn al-Helwe Palestinian refugee camp in Lebanon.

9 As is generally the case in Islamic studies, Suhr engages in research within the Muslim community of Gellerup, in Aarhus/Denmark. However, the majority of the residents are Palestinian. While he did not focus on Palestinian specificity, he nonetheless addresses their social practices, beliefs, and piety in particular. 
the field are, for instance, the study of Palestinian elites and well-established immigrants ${ }^{10}$ and the pattern and experience of Palestinian refugeeness compared to refugeeness among other Middle Eastern groups such as the Armenians (in historical perspective), Kurds, and Sahrawis ${ }^{11}$.

In a recent personal exchange, Rosemary Sayigh cautioned me against generalizing trends in Palestine Anthropology, given that the field is highly fragmented. She reasoned that many authors work across disciplinary borders, that there is no centralizing institution, and that many researchers commute between the Arab world and (especially) the USA. However, she prudently pointed out that the study of Palestinians in the diaspora does not follow the same trends ${ }^{12}$, and also suggested that there may have been a shift away from viewing Palestinian refugees primarily as nationalists and political actors, as expressed for example in Diana Allan's Refugees of the Revolution (2013). Sayigh's remarks about the field are indeed a welcome call to keep in check any facile generalizing characterizations. However, while plural, there are still some quite visible tendencies, such as the ones I described above, developing Furani and Rabinowitz's main arguments.

In Refugees of the Revolution, Allan states that "while the significance of transnationalism and diaspora for the formation of deterritorialized Palestinian identities has been explored [...] less attention has been paid to the local and rooted dimensions of Palestinian identity in exile" (Allan 2013: 214). She argues thus that political sympathy to the so-called Palestinian cause has created blind spots in Palestine anthropology, these being anything that does not fit the main official political discourse. According to her, Palestinian refugees have been portrayed in much of the field as noble sufferers, vivid in the act of memory and in the depth of their yearning for the past, but abstract subjects. Even ciphers, in the cultural and socioeconomic topographies of contemporary Lebanon. They exist in order to - and insofar as they - signify something about Israel/Palestine" (p. 215). An antidote to this would be her dialectical model, inspired by "radical empiricism" and "critical phenomenology" (p. 216), through which she advocates an ethical repositioning that "relies less on sympathy with a national cause, which produces

10 There are only very few articles about these themes, and usually from political scientists. A good example is (Rabe 2004). Besides, it must be acknowledged that elites and well established immigrants are predominant in the much isolated anthropological study of Palestinians in South America, usually under the rubric of Arabs and as secondary to Lebanese and Syrian. The specific anthropological study of Palestinians in the non-Middle Eastern diaspora has also intensely focused on "integration". Examples of such studies are (Shiblak 2005), (Karam 2013), (Hamid 2012), and (Schiocchet 2014). It must be noted that while Shiblak is not an anthropologist, a few articles in his collection engaged in ethnographic research.

11 (Chatty 2010) and (Farah 2009) are two insightful representatives of this countercurrent. I attribute the relative lack of comparative studies also partially to political differences between these groups, which tend to be reproduced in the academic environment.

12 With which I agree, since they quite isolated continue to pursue topics relating to immigration, transnationalism, and integration. 
problematic essentialisms, than on empathy, which recognizes alterity and the distances separating refugees, ethnographers, and their readers" (p. 224).

While I agree that her critique of nationalist inspired studies does indeed apply to a part of the field of Palestine Studies, I do not think that this is a significant part of the field. That is, in general, anthropologists have tended to avoid this trend perhaps more than other social scientists. In fact, to illustrate my point, I would be reticent to include almost all the authors mentioned in this section in this category. Nevertheless, Allan's project for a renewed Palestine Anthropology seems to fit perfectly well within the radical particularistic approach epitomized by Abu-Lughod's 1993 book. As she wrote:

This book is intended to present, in the form of a narrative ethnography, made up of these women's stories and conversations, a general critique of ethnographic typification [...] to explore how the wonderfully complex stories of the individuals I had come to know in this community in Egypt, might challenge the capacity of anthropological generalizations to render the lives, theirs or others, adequately (Abu-Lughod 2008: vii) - this is to be achieved through the portrayal of "the languages of everyday life" (Abu-Lughod apud Lindholm 1995). To mention Abu-Lughod here is opportune, since Allan's book is meant to "critique the politics of solidarity", the "romance of resistance" (Abu-Lughod 1990) (Allan 2013: 222).

Most abovementioned authors fit well within this project, such as Davis, Khalili, Sa'adi, Slyomovics, Schiocchet, or Swedenburg. According to Allan, "the conceptual potency of nationalism for refugees in exile has been overemphasized, I am not saying it is obsolete" (p. 223). I agree that anthropologists must maintain a critical distance from the nationalist discourse and watch closely how the refugees feel and express themselves. However, the language of nationalism is integral to the routine of many Palestinians not only in the Near East, although not expressed in words everywhere. The reach of the nationalist doxa is much wider in the present. It is constantly resignified by the refugees and embodied in dispositions and socio-cultural idioms, while projects, motivations, feelings, and goals are very often different from those prescribed by the political offices of its inceptors (Schiocchet 2011). In other words, although we must not study the nationalist doxa as immutable and homogenously expressed everywhere, in most cases, it has become at minimum a moral imperative, but also frequently a language of expression that must be accounted for and dealt with, even if only to be rejected.

Finally, although I do agree with Abu-Lughod and Allan that in the early 1990's anthropology had yet to come to terms with the devastating critique propelled by authors such as Said and Asad in the late 1970's, today we are in a different historical moment. While Abu-Lughod and Allan's richly detailed and particularistic accounts are always going to be welcomed, this is not the only project that the field can support. To emphasize heterogeneity among Palestinian refugees in Lebanon, for instance, we must compare different ethnographies, and engage in multisited comparative ethnography (Hannerz 2003). Wider comparative ethnographic work should not be seen as intrinsically contrary to the particularistic 
approach, but complementary. While the latter has been the focus for decades, the first is heavily underrepresented, largely left for the geographers, sociologists, and political scientists. Current Palestine anthropology not often acknowledges that a comparative contextual approach can act as an antidote where a more essentialist approach itself may incur overgeneralization.

We have to be cautious so as not to picture Palestinian anthropology as lost in blind activism, and so as not to jettison from the picture what most refugees claim to bind them together: not so much an orthodox national discourse, but the collective suffering associated with exile and loss at large, along with the polyphonic language of "The Palestinian Cause" through which this suffering is very frequently expressed. As Allan's own interlocutor claims, "the hardship we have lived is very important. It is this suffering that draws us to the camp - not happiness, because when you are happy, you don't need to reflect on your situation" (Allan 2013: 218).

\section{The Ethnographic Suffering}

Recently, in another article in the JRAI, Joel Robbins addressed the pivotal shift from an "anthropology of the savage" to one of the "suffering subject", claiming that many of the pitfalls of the latter can be readdressed through an "anthropology of the good" (2013). The current accent on political, religious, ethnic, and gender minorities reflects the contemporary world's ubiquitous political expression of civic contestation. As I mentioned at the beginning of this essay, Didier Fassin notes that as its subject shifts from "the other" to "the public", anthropology itself becomes more public (2013). Subaltern studies have long since pointed toward the postcolonial nature of the world today. Far and wide, minority conflicts reflect unique processes of settling ethnic, religious, political, and economic disputes, as subjects struggle between national citizenship and post-national political representation. Not only is the Israeli-Palestinian conflict emblematic of this debate, but Middle East, and especially Palestine, based theory was one of the vortexes of this once new anthropological trend, as stated respectively by Lindholm, and Furani and Rabinowitz. In this section, I explore what Robbins identifies as the shift from an anthropology of the Other to an anthropology of the Human through the "suffering subject", and ask what the new trend can learn from Palestine ethnography?

Thanks to Said, Asad, Abu-Lughod, Sayigh, Peteet, Furani, Rabinowitz, Allan, and others, memory, dispossession, struggle, refugeeness, diaspora, citizenship, statehood, the relationship between resistance and agency, and, binding them all, suffering, are some of the main themes of current Palestine ethnography, even more so than in Middle Eastern ethnography at large. As Allan claims, it is imperative for ethnographers to detach themselves from any official nationalist discourse 
(whatever version of it), but not as much from the reality on the ground (what we experience among the people we study). With Allan, I also hold that many of the above themes and perspectives come from the general engaged observer position of the contemporary Palestine ethnographer, although I find it fair to say that this positioning mostly came from the stated claims of the Palestinians themselves, especially refugees. Such themes emerged not simply from the realm of European theory, self-critique and guilt, but as an entailment of praxis - perhaps as Furani and Rabinowitz hope - through the anthropological encounter that made many anthropologists into engaged observers, and from then on also through engaged observers who influenced a whole generation of anthropologists. Common to the Palestinians' own experience everywhere (as I have often heard from them) is the trope that the Palestinian refugee from Allan's book mentioned above emblematically expresses: "suffering". Thus, both as a Western critique as we saw in the first two sections, and as an effort to tackle the dramatic reality of much of the world today, anthropologists have engaged with the reality of human suffering. But who is the "suffering subject" of contemporary ethnography, and how did this shift of emphasis change anthropological theory?

As stated by Lindholm, by the early 1990's the critique to the anthropological othering of the world initiated in the late 1970's had already deeply affected anthropology, and perhaps even more strongly Middle Eastern ethnography. According to him, some of anthropology's main vocations were at risk of being lost on the way. Welcoming the change, Furani and Rabinowitz show how it affected Palestine as a site of ethnographic inquiry, while proposing ways in which Palestine bound theory could help reshape Western anthropological thought. Although not overtly stated, Lindholm seems to have been already aware of and grappling with how a new anthropological focus on the human condition was in-the-making, influencing reactions to what was widely perceived then as a "crisis" - vide my highlights of Lindholm's and other writers' mentions relating to humanity and suffering throughout this essay. Written much later, and following Michel-Rolph Truillot's 1991 Anthropology and the Savage Slot (Truillot 2003) in its diagnosis, Robbins' Beyond the Suffering Subject overtly claims that the suffering subject replaced the Other as primary object of anthropological attention. While with Furani and Rabinowitz he also welcomes the general critique, like Truillot and Lindholm he also understands that some of anthropology's "unique critical capacities" were "lost in transition". To him, two of these critical capacities are, "the cultural point and the critical potential of the notion of difference" (Robbins 2013: 447) - both of which, I stress, entail comparison.

Already throughout the 1980's, anthropologists such as Michael Fischer, Lila Abu-Lughod, Johannes Fabian, James Clifford and George Marcus had begun to criticize anthropological othering and the misrepresentation of others. As we have seen, in Palestine ethnography this phase was marked especially by the Palestinians' conquest of their own nation as a site of inquiry. According to Robbins, it was 
only in the early 1990's that anthropology started to move away from the focus on the Other and conglomerate around the image of the suffering subject (Robbins 2013). Yet, as I have shown, already since the late 1970's Palestinian suffering has been the hallmark of the Palestine chapter of ethnography, which largely turned to the study of refugees and was increasingly written by Palestinians themselves.

Still following Truillot, Robbins thinks that these changes to anthropology were rooted in a societal change of the ways in which the Western world had come to picture what was once called "the savage", and that the way forward should be informed by such transformations. Truillot and Robbins cite Humanitarian thought and intervention as one of the main recent societal changes affecting anthropology, making a "humanity united in its shared vulnerability to suffering" its main focus of research (p. 450). Not surprisingly then, the suffering subject to Robbins is that who is "living in pain, in poverty, or under conditions of violence or oppression" (p. 448).

In his many talks about the Urapmin, Robbins learned that his audience made sense of them through empathy by fitting them into the suffering slot, since being Christian took them out of the savage category. This illustrates the early 1990's anthropological change, marked by a shift from "analytic distance and critical comparison focused on difference" to "empathic connection and moral witnessing based on human unity", trauma being the "bridge between cultures" (p. 453), and the whole process generating a "communion in trauma" (Fassin apud Robbins 2013).

According to Robbins, some, such as Valentine Daniel, went as far as to state that "suffering remains beyond culture", meaning that they "would not require cultural interpretation" to render it "sensible" (Robbins 2013: 454). While it is debatable whether Daniel's work would indeed fit this radically humanist anthropology so smoothly, more emblematic of this effort is João Biehl's work on suffering $(2005,2013)$ - also mentioned by Robbins. While the axiom of radical particularism was the incommensurability of cultural phenomena, and any attempt at competence on the Other's culture could be seen as reductionism or imperialist, the axiom of radical humanism is that cultural diversity is just a membrane to be shed in order to find deeper common-to-all meaning.

Not as critical of the trend as Lindholm was in 1995, Robbins hopes for yet another theoretical turn, one that in fact he sees within reach. Some of the most recent trends in anthropology - he explains - such as those discussing "time", "the gift", "value", "morality", "hope", "well-being", "empathy", "care", and "imagination" (perhaps we may say, "memory"), may coalesce in an "anthropology of the good", "capable of recovering some of the distinctive critical force of an earlier anthropology without taking on many of its weaknesses" (p. 448). To him, what is worth recuperating is the anthropological notion that cultural diversity can teach us about "our own" culture. 
Nonetheless, taking the broad picture of the field into account, populated by the emphasis on minorities of all sorts, I suggest that the suffering subject is yet another way to state that contemporary anthropologists have written primarily against Western, white, heterosexual, male and normativity at large, essentially transforming anthropology from Western cultural critique to cultural critique of the Western world. Therefore, I do not agree with Robbins that the suffering subject brought the sunset of the Other as a main theme of anthropological inquiry. Rather, the Other is still very much alive, though often reduced to what we could call a "bare life" (Agamben 1998, 2005) image of ourselves. It is debatable whose culture is "our own" (or Robbins') in a much more inclusive and less Western normative contemporary anthropology.

Thus, an "anthropology of the good" - "imaginatively conceived, not simply perceived" (Robbins 2013: 457) - striving to learn different cultural projects to make sense of life, holds promise to recuperate anthropology's comparative vocation, while retaining its contemporary cultural critique of the Western normativity character. Yet, Robbins' anthropology may benefit from a more nuanced reading of the anthropology of suffering as expressed, for example, by Veena Das. For the latter, while "critical and traumatic events" are "not simply constituted by forms of the social", they are "not wholly its other either" (Das 2007: 7). "Anthropologists cannot simply take comfort in any simple notion of innocent victims or the work of culture as a pregiven script" (Das 2007: 220). Given that "ordinary" is where the "unknowability of the world and hence of oneself" is located, engaging people's lives and their suffering is a "descent into the ordinary", capable of "recovering life" (Das 2007: 7) through "inhabiting it as in a gesture of mourning for it" (idem: 77) more than through "grand gestures in the realm of the transcendent" (Das 2007: 7). Thus, here too I grasp both ends of this tug of war. On the one end, if anthropology is to continue to use the notion of culture at all, as opposed to its multiple substitutes, then we must once more be cautious so as not re-craft reifying tools, or we risk leaving behind the main contributions of critical anthropology (mainly, its politicized posturing of putting oneself and one's own individual and social self into perspective). On the other end, to mourn (a critical expression of empathy) is certainly laudable, if not necessary, but it is certainly not enough. Anthropology does need contextual tools. It must recover comparison so as to remain critical, to transcend yet not expect a supposed apolitical stance, but to gain perspective. And yet, to remain critical is also not enough.

Didier Fassin's project for ethnography is that of John Van Maanen's "critical tale": "inscribing the description of the scenes and situations in the social structure and the historical context - which is probably the terrain where the two projects of popularizing and politicizing ethnography intersect". In this sense, "public anthropology" holds "the principle of bringing to multiple publics [by which he means publics beyond the academic circles] the findings of an ethnography analyzed in light of critical thinking, so that these findings can be apprehended, 
appropriated, debated, contested, and used" - contributing to "a transformation of the way the world is represented and experienced" (2013: 628). As Fassin states, "to play its possible social role, ethnography must be simultaneously critical and public" (2013: 642), and however critical anthropology (and especially ethnography) may be even after its 1990's transformation, it is still not as "public" as it needs to be.

\section{Conclusion: Suffering as Critique?}

As Sherry Ortner (2016) assesses, Robbins' "anthropology of the good", along with the focus on morality and ethics (p. 59), well-being (p. 58), and care, love, empathy, and responsibility (p. 60), is itself a reaction to what she calls "dark anthropology", or "anthropology that focuses on the harsh dimensions of social life (power, domination, inequality, and oppression), as well as on the subjective experience of these dimensions in the form of depression and hopelessness" (p. 47), including the anthropology of the suffering subject. According to Ortner, the rise of dark anthropology reflects the influence of Karl Marx and Michel Foucault and consists of "theory that asks us to see the world almost entirely in terms of power, exploitation, and chronic pervasive inequality" (p. 50). Moreover, this trend is influenced by the rise of postcolonial theory within anthropology, notably through Talal Asad's Anthropology and the colonial encounter (1973) (Ortner, 2016: 49). More to the point, "in the wake of the work of Talal Asad, Edward Said, and eventually many others, the field as a whole was quite literally transformed" (p. 51). Within this transformation, Ortner also locates under "cultural critique", among other things, "critical empirical studies, including both ethnohistorical studies in the case of colonialism, and more strictly ethnographic studies" (p. 62), within which I perceive Abu-Lughod's works at least until the early 1990s. Ortner explicitly includes within this group at least Media worlds: Anthropology on new terrain (2002), edited by Faye D. Ginsburg, Lila Abu-Lughod, and Brian Larkin (Ortner 2016: 62).

From the anthropology of the good and that of ethics, Ortner takes that "the study of power and inequality, and the damage they do, cannot be the whole of anthropology" (Ortner 2016: 60) and that "it is important to look at the caring and ethical dimensions of human life" (p. 60). However, in line with darker anthropologies, she also reasons that the anthropology of the good sometimes frames "work on the good in opposition to work on oppression and inequality (dismissed as "misery porn")" or "simply ignore[s] the larger contexts of power and inequality in play" (p. 65). She coalesces both dimensions into what she calls a "different kind of anthropology of the good: the anthropology of critique, resistance, and activism" (p. 60), which "includes both 'cultural critique' - that is, the critical study of the existing order - and studies that emphasize thinking about alternative 
political and economic futures" (p. 66). She uses the term "resistance" to cover "a range of modes of (anthropological) engagement with political issues: critical theoretical discussions; critical ethnographic studies; studies of political movements of all kinds; activist anthropology; and more" (p. 61).

In his critique to Ortner's Dark Anthropology, James Laidlaw (2016) defends that the rift between dark anthropology and the anthropology of the good is in essence a mistake created by the wrong way anthropologists read Foucault as merely an elaboration of Marx, rather than in opposition to him, - an opposition more clearly reflected in Foucault's latest works. However, like Ortner, I take Robbins' (and Laidlaw's) project with a grain of salt and welcome the necessity of a compromise between dark anthropology and anthropology of the good. As I perceived among Palestinian refugees, suffering is perhaps better understood as a total social fact embedded in the quotidian, rather than an exclusive domain of social life. As such, suffering must be qualified according to people's own ideals, values, conceptions of morality, and practices, as proposed by the proponents of the anthropology of the good and ethics. But it must also be acknowledged that suffering is inherently intertwined in power relations that must be spelled out if one is to obtain deep knowledge about the social situation analyzed. However, an anthropology of resistance in Ortner's terms might not be the most appropriate term to qualify what I propose here, since a general focus on resistance may also underplay the larger context within which the suffering of, for example those Palestinian refugees among whom I carried out fieldwork, takes place. The compromise proposed by Ortner must thus be enlarged to include broader comparative efforts that do not lose sight of the uniqueness of each social situation analyzed, or of broader social and political processes at play in regional and global scales.

Twenty years after Lindholm's JRAI's article, in 2013, Sherine Hafez and Susan Slyomovics's Anthropology of the Middle East and North Africa: Into the New Millennium (2013) reviewed the anthropology of contemporary MENA in view of the so-called Arab Spring still stressing anthropology's efforts to come to grips with issues of representation and political positioning at large, and especially with the de-essentialization of the Middle East. In this edited volume, Slyomovics', Seteney Shamy and Nefissa Nagib's, and Lara Deeb and Deborah Winegar's chapters directly acknowledge the lasting impact of Abu-Lughod's work as a logical continuity of Said's critique, and criticize Carleton Coon's famous "mosaic" metaphor as an assemblage of essentialized, well-defined, homogenous and harmonious subjects that underplays the complex, contextual and shifting character of social cleavages. According to Deeb and Winegar, Coon's mosaic perspective is still present in the scholarship on the Middle East today through "ethnographic silence" (Hafez, Slyomovics 2013: 219), hence the need to still de-essentialize Middle East anthropology. However, covering different cases while discussing a pressing topic, Hafez and Slyomovics cannot be simply taken as an example of Abu-Lughod's particularistic trend as Lindholm saw it in 1995, but as an example of how contemporary 
Middle East anthropology has now often been making good use of Abu-Lughod's past insights ${ }^{13}$ without necessarily sharing its imitations. While comparison is still relatively lacking in Palestine anthropology, it seems to be slowly resurrecting in Middle East anthropology at large.

However, whichever new topics we decide to explore from now on, and whichever compassion we decide to pursue, we must not forget the commitment we assumed since the late 1970's with what Lindholm once called "new" Middle Eastern ethnography, which today is already "classic". The maintenance of a critical stance toward all normativity (and, in particular, Global North's normativity) is essential to the future of anthropology, and giving voice to the suffering of others should be integral to the ethics of ethnography. However, as with any other anthropological project, this also has its pitfalls. Radical particularism is sometimes a form of essentialization, and the absence of comparison is often a disadvantage. If what we needed in the 1980's was detachment from nationalist projects and Western imperialism, today we need further detachment also from the humanitarian discourse, and especially from the emphasis on the "bare life" of others. An anthropology of the good holds some promise as a way to refine the collaborative ethnographic approach to other projects of society - or what Hans-Georg Gadamer called "fusion of horizons" (2011) - not as cultural representation or translation, or mere Westward critique. If collaborative enough, anthropologists will remain empathetic to the suffering of others without the need to posit the anthropological effort squarely into the Western imperialist fold.

As Turki's opening quotation expresses, suffering is common to the Palestinian experience everywhere. However, not unqualified suffering that reminds us we are all Human, but qualified suffering as an essence shared only among those who went through one of its particular iterations. In this sense, two of the main themes of Palestinian public expressions of suffering, in many ways reappropriated through activism, are the ongoing character of the $\mathrm{Nakba}^{14}$, and the drive against narratives of pure victimization towards narratives of resistance. Both are part of a same set of discourses, colored by the concept of "The Palestinian Cause", and thus inherently intertwined. While the first calls for witnessing Palestinian suffering, the second qualifies how that suffering must be apprehended. As I developed elsewhere, among refugees, and ironically largely through PLO nationalist jargon that has gone out of the PLO's control, resistance needs not be experienced as bellicose or even apart from routine, but can be essentially embedded in the quotidian ${ }^{15}$ and experienced in all dimensions of social life $(2015,2013)$. Closing this two-element

13 Abu-Lughod seems today much less prone to equate broad analytical categories with empty generalization than she was in the early 1990's.

14 In Arabic, "The Catastrophe" - the 1948 creation of Israel and Palestinian refugeeness.

15 It does not follow that all Palestinian agency is resistance - see, for instance (Mahmood 2005) only that resistance is embedded in much of daily life, rather than only present when expressed overtly. 
circuit, among Palestinians, existence as a refugee is already widely understood as resistance, just as suffering entails resistance. The theoretical implication of this Palestinian understanding is one of the possible contributions to Furani and Rabinowitz's pursuit of how, after Said, Palestine theory can continue to influence anthropological theory at large. This amounts to what Dipesh Chakrabarty (2000) called "provincializing Europe", a movement aimed at denaturalizing European influence on thought elsewhere in the world, rather than one aimed at purging, for example, Palestinian thought of every and any sign of European influence.

Lindholm reminds us that anthropology is inherently comparative. Nevertheless, just as with suffering, comparison should always be qualified. It is only when context and comparison are integral to the picture that anthropologists are truly localized and engaged. Therefore, cultural (or social) critique should remain an integral part of the contemporary anthropological project. Rather than a tool of disengagement, fruitless abstraction, and ungrounded speculation, qualified comparison is not only compatible with critical perspectives such as subaltern and postcolonial studies, but intrinsic to the critique of Western reason itself.

\section{Bibliography}

Abufarha N.

2007 The Making of the Human Bomb: An Ethnography of Palestinian Resistance, Durham.

Abu-Lughod L.

1989 Zones of Theory in the Anthropology of the Arab World, "Annual Review of Anthropology", vol. 18, p. 267-306.

1990 The Romance of Resistance: Tracing Transformations of Power Through Bedouin Women, "American Ethnologist", vol. 17, no. 1, p. 41-55.

2008 Writing Women's Worlds: Bedouin Stories, Berkeley.

Abu-Lughod L., Sa'di A. (eds.)

2007 Nakba: Palestine, 1948, and the Claims of Memory, New York.

Agamben G.

1998 Homo Sacer: Sovereign Power and Bare Life, trans. D. Heller-Roazen, California. 2005 State of Exception, trans. K. Attel, Chicago.

Agier M.

2008 On the Margins of the World: The Refugee Experience Today, Malden.

2011 Managing the Undesirables: Refugee Camps and Humanitarian Government, Cambridge, UK.

Allan D.

2013 Refugees of the Revolution: Experiences of Palestinian Exile, Stanford.

Allen L.

2013 The Rise and Fall of Human Rights: Cynicism and Politics in Occupied Palestine, Stanford.

Antoun R. 
1989 Muslim Preacher in the Modern World: A Jordanian Case Study in Comparative Perspective, Princeton.

Asad T.

1993 Genealogies of Religion: Discipline and Reason of Power in Christianity and Islam, Baltimore.

2009 The Idea of an Anthropology of Islam, "Qui Parle”, vol. 17, no. 2, p. 1-30.

Asad T. (ed.)

1973 Anthropology and the Colonial Encounter, London.

Barbosa G.

2013 Non-cockfights: On Doing / Undoing Gender in Shatila, Lebanon, Ph.D. thesis, London School of Economics.

Biehl J.

2005 Vita: Life in a Zone of Social Abandonment, Berkeley.

2013 Ethnography in the Way of Theory, "Cultural Anthropology", vol. 28, issue 4, p. 573-597.

Bowen D.L., Early E. (eds.)

1993 Everyday Life in the Muslim Middle East, Bloomington.

Bowman G.

2011a "In dubious Battle on the Plains of of Heav'n": The Politics of Possession in Jerusalem's Holy Sepulcher, "History and Anthropology" XXII, vol. 3 (September), p. 371-399.

2011b Identification and Identity Formations around Shared Shrines in West Bank Palestine and Western Macedonia in: D. Albera, M. Couroucli (eds.), Sharing Sacred Spaces in the Mediterranean: Christians, Muslims, and Jews at Shrines and Sanctuaries, Bloomington, p. 10-28.

2013 Popular Palestinian Practices around Holy Places and Those Who Oppose Them: An Historical Introduction, "Religion Compass", vol. 7 (March), p. 69-78.

Burke E. (ed.)

1993 Struggle and Survival in the Modern Middle East, London.

Chakrabarty D.

2000 Provincializing Europe. Postcolonial Thought and Historical Difference, Princenton, New Jersey.

Chatty D.

2010 Displacement and Dispossession in the Modern Middle East, Cambridge.

Clifford J.

1988 The Predicament of Culture, Cambridge.

Colson E.

2003 Forced Migration and the Anthropological Response, "Journal of Refugee Studies", vol. 16 , no. 1, p. 1-18.

Das V.

2007 Life and Words: Violence and the Descent into the Ordinary, Los Angeles.

Davis R.

2010 Palestinian Village Histories Geographies of the Displaced, Stanford.

Dias A.

2013 Aux marges de la ville et de l'Etat: Camps palestiniens au Liban et favelas cariocas. Paris. 
Doumani B.

1995 Rediscovering Palestine: Merchants and Peasants in Jabal Nablus, 1700-1900. Los Angeles.

Eickelman D.

1985 Knowledge and Power in Morocco: The Education of a Twentieth-Century Notable, Princeton.

Farah R.

1997 Palestinian Refugees and the UNRWA: Oral History and Popular Memory in: A History within History: Oral History and Popular Memory. Amman.

1998 UNRWA in Popular Memory al-Baq'a Refugee Camp in: A History within History: Humanitarian Aid and Development, Amman.

2003 Palestinian Refugee Camps Reinscribing and Contesting Memory and Space in: C. Strange, A. Bashford, Isolation Places and Practices of Exclusion, New York-London. 2009 Refugee Camps in the Palestinian and Sahrawi National Liberation Movements: A Comparative Perspective, "Journal of Palestine Studies", no. 150, vol. XXXVIII, no. 2, p. 76-93.

Fassin D.

2008 The Humanitarian Politics of Testimony: Subjetification through Trauma in the Israeli-Palestinian Conflict, "Cultural Anthropology", vol. 23 (3), p. 531-558.

2012 Humanitarian Reason: A Moral History of the Present, Los Angeles.

2013 Why Ethnography Matters: On Anthropology and its Publics, "Cultural Anthropology", vol. 28, issue 4, p. 621-646.

Feldman I., Ticktin M. (eds.)

2010 In the Name of Humanity: The Government of Threat and Care, Durham.

Feldman I.

2008 Governing Gaza: Bureaucracy, Authority and the Work of Rule, 1917-1967. Durham.

Fischer M.

1980 Iran: From Religious Dispute to Revolution, Cambridge, MA.

Furani K.

2011 The Ethnographic arriving in Palestine, Georgetown CCAS. http://vimeo. com/30555956. (access: 18.04.2014).

Furani K., Rabinowitz D.

2011. The Ethnographic Arriving of Palestine, "Annual Review of Anthropology", vol. 40, p. 475-491.

Gabiam N.

2006 Social Thought and Commentary: Negotiating Rights: Palestinian Refugees and the Protection Gap, “Anthropological Quarterly”, vol. 79, no. 4 (Autumn, 2006), 717-773.

Gadamer H.-G.

2011 Truth and Method, New York.

Hafez S., Slyomovics S.

2013 Anthropology of the Middle East and North Africa: Into the New Millennium, Indianapolis.

Hamid S.C.

2012 (Des)Integrando Refugiados: Os Processos do Reassentamento de Palestinos no Brasil (in Portuguese), doctoral thesis, Universidade de Brasilia (Brazil).

Hammoudi A.

1993 The Victim and its Masks: An Essay on Sacrifice and Masquerade in the Maghreb, Chicago. 
Hammami R.

2003 Gender, Nakbe and Nation: Palestinian Women's Presence and Absence in the Narration of 1948 Memories in: R. Robin, B. Strath. Homelands: Poetic Power and the Politics of Space, Brussels.

Hannerz U.

2003 Several Sites in One in: T.H. Eriksen (ed.), Globalisation, London.

Jayyusi L.

2002 Letters from the Palestinian Ghetto: 8-13" March 2002, "Critical Arts", vol. 16, no. 1, p. 125-129.

2007 Iterability, Cumulativity, and Presence in: A. Sa'di, L. Abu-Lughod, Nakba: Palestine, 1948, and the Claims of Memory, p. 107-134, New York.

Kanaana S.

1989 Speak Bird, Speak Again, Los Angeles.

2000 Still on Vacation!: The Eviction of the Palestinian in 1948, Jerusalem.

Kanaaneh M., Thorsén S.-M., et al. (eds.)

2013 Palestinian Music and Song: Expression and Resistance since 1900, Bloomington.

Kanaaneh R.A., Nusair I.

2010 Displaced at Home: Ethnicity and Gender among Palestinians in Israel, Albany.

Karam J.T.

2013 On the Trail and Trial of a Palestinian Diaspora: Mapping South America in the Arab-Israeli Conflict, 1967-1972, "Journal of Latin American Studies" 45.5 (November), p. 751-777.

Kassir S.

2006 Being Arab, London.

Khalili L.

2005 Places of Memory and Mourning: Palestinian Commemoration in the Refugee Camps of Lebanon, "Comparative Studies of South Asia, Africa and the Middle East", vol. 25.1, p. 30-45.

2007 Heroes and Martyrs of Palestine: The Politics of National Commemoration, New York.

Knudsen A.

2003a Islamism in the Diaspora: Palestinian Refugees in Lebanon, "CMI Working Paper", vol. 10, p. 23.

2003b Political Islam in the Middle East, "CMI Report", p. 32.

Knudsen A., Hanafi S. (eds.)

2011 Palestinian Refugees: Identity, Space and Place in the Levant, London.

Kublitz A.

2001 The Sound of Silence: The Reproduction and Transformation of Global Conflicts within Palestinian Families in Denmark in: M. Rytter, K.F. Olwig (orgs.), Mobile Bodies, Mobile Souls: Family, Religion, Migration in a Global World, Aarhus.

2016 From Revolutionaries to Muslims: Liminal Becomings across Generations among Palestinians in Denmark, "International Journal of Middle East Studies", vol. 48 (1), p. 67-86.

Laidlaw J.

2016 Through a Glass, Darkly, "HAU: Journal of Ethnographic Theory", vol. 6 (2), p. 17-24. 
Lindholm C.

1995 The New Middle Eastern Ethnography, "Journal of the Royal Anthropological Institute", vol. 1, no. 4 (December), p. 805-820.

2002 The Islamic Middle East: Tradition and Change, Malden/MA.

Lybarger L.D.

2007 Identity and Religion in Palestine: The Struggle between Islamism and Secularism in the Occupied Territories, New Jersey.

Mahmood S.

2005 Politics of Piety, New Jersey.

Malkki L.

1995 Purity and Exile: Violence, Memory, and National Cosmology among the Hutu Refugees in Tanzania, Chicago.

Messick B.

1993 The Calligraphic State: Textual Domination and History in a Muslim Society, Berkeley.

Munson H.

1993 Religion and Power in Morocco, New Haven.

Ortner S.

2016 Dark Anthropology and its Others, "HAU: Journal of Ethnographic Theory", vol. 6 (1), p. 47-73.

Peteet J.

1987 Socio-Political Integration and Conflict Resolution in the Palestinian Camps in Lebanon, "Journal of Palestine Studies", vol. 16 (2), p. 29-44.

1994 Male Gender and Rituals of Resistance in the Palestinian "Intifada": A Cultural Politics of Violence, "American Ethnologist" vol. 21(1), p. 31-49.

1996a From Refugees to Minority: Palestinians in Post-War Lebanon, "Middle East Report", vol. 200, p. 27-30.

1996b Transforming Trust: Dispossession and Empowerment among Palestinian Refugees in: E.V. Daniel, J.C. Knudsen (eds.), Mistrusting Refugees, Los Angeles.

2005, Landscape of Hope and Despair: Palestinian Refugee Camps, Philadelphia.

Rabe H-J.

2004 Palestinian Territories: From State Building to Crisis Management in: V. Perthes, (ed.), Arab Elites: Negotiating the Politics of Change, Boulder/CO.

Robbins J.

2013 Beyond the Suffering Subject: Toward an Anthropology of the Good, "Journal of the Royal Anthropological Institute", no. 19, p. 447-462.

Rosen L.

1989 The Anthropology of Justice: Law as Culture in Islamic Society, Chicago.

Rougier B.

2007 Everyday Jihad: The Rise of Militant Islam among Palestinians in Lebanon, Cambridge/MA.

Sa’ar A.

1998 Carefully on the Margins: Christian-Palestinians in Haifa between Nation and State, "American Ethnologist", vol. 25(2), p. 214-239.

Sa'di A.H., Abu-Lughod L. (eds.)

2007 Nakba: Palestine, 1948 and the Claims of Memory, New York.

Said E.

1979 Orientalism, New York. 
Salih R.

2013 Reconciling Return and Rights: Palestinian Refugees and the Emergence of a "Political Society" in: Jadaliyya, http://www.jadaliyya.com/pages/index/10814/reconcilingreturn-and-rights_palestinian-refugees_access: 04.22.2014).

Sayigh R.

1979 The Palestinians: From Peasants to Revolutionaries, London.

1994 Too Many Enemies, London.

2007 Women's Nakba Stories in: A. Sa'di, L. Abu-Lughod. (eds.), Nakba: Palestine, 1948, and the Claims of Memory, 135-160, New York: Columbia University Press.

Schiocchet L.

2011 Far Middle East, Brave New World: The Building of the Middle East and the Arab Spring, "The Perspective of the World Review", vol. 3, no. 2, August, p. 37-80.

2013 Palestinian Sumud: Steadfastness, Ritual and Time among Palestinian Refugees in: A. Khalil (ed.), Palestinian Refugees: Different Generations but One Identity, Palestine.

2014 The Least of "The Undesirables": 117 Palestinian Refugees in Brazil between Humanitarianism and Nationalism, paper presented at Refugee Voices: Refugee Studies Centre International Conference 2014, Oxford University.

2015 Palestinian Steadfastness as a Mission in: A. Horstmann, J. Jin-Heon (eds.), Building Noah's Ark for Refugee, Migrants and Religious Communities, London.

Segal L.B.

2014a Disembodied Conjugality in: C. Roma (ed.), Wording the World: Veena Das and the Scenes of Inheritance, New York.

2014b Mourning, Containment and the Loss of politics in Palestine - The Unvoiced Effects of Military Occupation in the west Bank in: C. Han, V. Das (eds.), An Anthropology of Living and Dying in the Contemporary World, Los Angeles.

Shiblak A.

2005 The Palestinian Diaspora in Europe: Challenges of Dual Identity and Adaptation, Beirut.

Slyomovics S.

1998 The Object of Memory: Arab and Jew Narrate the Palestinian Village, Philadelphia. Suhr C.

2013 Descending with Angels: The Invisible in Danish Psychiatry and Islamic Exorcism, Ph.D. thesis, Aarhus University.

Swedenburg T.

1992 Occupational Hazards: Palestine Ethnography in: G. Marcus (ed.), Rereading Cultural Anthropology, p. 69-76, Durham.

2003 Memories of Revolt: The 1936-1939 Rebellion and the Palestinian National Past, Fayetteville.

Truillot M.-R.

2003 Global Transformations: Anthropology and the Modern World, New York.

Turki F.

1974 The Disinherited: Journal of a Palestinian in Exile, New York.

Varisco D.

2004 Terminology for Plough Cultivation in Yemeni Arabic, "Journal for Semitic Studies", vol. 49 (1), p. 71-129. 